AL-MARSHAD: JURNAL ASTRONOMI ISLAM DAN ILMU-ILMU BERKAITAN

ISSN 2442-5729 (print) || ISSN 2598-2559 (online)

http://jurnal.umsu.ac.id/index.php/almarshad

DOI: 10.30596/jam.v5i1.2743 || Vol. 5, No. 1 Juni 2019

\title{
Pragmatisme Charles S. Peirce dan Implikasinya Pada Penentuan Awal Waktu \\ Salat dan Pelaksanaannya
}

\author{
Arjuna Hiqmah Lubis
}

Universitas Islam Negeri Walisongo Semarang

email: arjunahiqmahlubis@gmail.com

\begin{abstract}
Philosophers through their philosophy continue to provide ideas in defining something that is in accordance with each. Charles Sanders Peirce with his school of philosophy Pragmatism. Peirce is an expert in various fields of science such as mathematics, chemistry, geodesy. Then this fantasy genre of pragmatism attracted many Americans and also in various parts of Europe through his friend William James. Flow Pragmatism

\section{Keywords: Philosophy, Pragmatism, Charles S. Peirce, Prayer Times}

Abstrak

Filsuf melalui filsafatnya terus memberikan hasil pemikiranpemikiran dalam mendefenisikan sesuatu sesuai dengan masanya masing-masing. Begitu juga pada masa abad ke-19 di daratan benua Amerika yang juga memiliki ahli pikir diantaranya tokoh yang paling terkenal adalah Charles Sanders Peirce dengan aliran filsafatnya Pragmatisme. Peirce adalah seorang pakar diberbagai bidang ilmu seperti matematika, kimia, geodesi dan lain sebagainya. Kemudian aliran pemikirannya ini tentang pragmatisme menarik minat banyak orang-orang Amerika dan juga di berbagai daerah Eropa melalui sahabatnya William James. Aliran pragmatism ini memandang bahwa kriteria kebenaran ajaran adalah, faedah atau manfaat.
\end{abstract}

Artikel Info

Received:

17 Januari 2019

Revised:

15 Februari 2019

Accepted:

23 April 2019

Published:

02 Juni 2019

Kata Kunci: Filsafat, Pragmatisme, Charles S. Peirce, Waktu Salat

\section{A. Pendahuluan}

Pragmatisme merupakan aliran pemikiran yang lahir di Amerika pada era 1870-an, hampir satu setengah abad yang lalu. Kini, defenisi kata "pragmatis" sering dikaitkan dengan kepentingan praktis, keengganan berproses, atau berorientasi semata pada pencapaian hasil. Kita sering mendengar penggunaan kata 


\section{AL-MARSHAD: JURNAL ASTRONOMI ISLAM DAN ILMU-ILMU BERKAITAN \\ ISSN 2442-5729 (print) || ISSN 2598-2559 (online) \\ http://jurnal.umsu.ac.id/index.php/almarshad \\ DOI: 10.30596/jam.v5i1.2743 || Vol. 5, No. 1 Juni 2019}

"pragmatis" yang mengacu pada definisi ini pada berita-berita di koran atau televisi yang misalnya menyatakan: pendidikan yang hanya mengejar gelar ialah pendidikan yang pragmatis; politik untuk meraup keuntungan pribadi/ kelompok merupakan politik yang pragmatis: pasal-pasal serta hukuman yang bisa diperjualbelikan menunjukkan hukum yang pragmatis; agama sebagi komoditas adalah sebagai bentuk penghayatan agama yang pragmatis, dan sebagainya. Pragmatis mulanya merupakan metode dalam bidang epistemologi untuk menjelaskan makna gagasan. ${ }^{1}$

Charles S. Peirce dikenal sebagai pelopor filsafat analitik disamping dikenal pula sebagai pendiri aliran pragmatisme. Dia membentuk satu teori diantara teori-teori modern tentang makna dengan mengusulkan satu teknik untuk menjelaskan pikiran. Hal ini dapat ditemukan dengan baik jika menempatkan pikiran tersebut dalam ujian eksperimental dan mengamati hasilnya. Ukurannya tentang makna adalah dengan memerhatikan

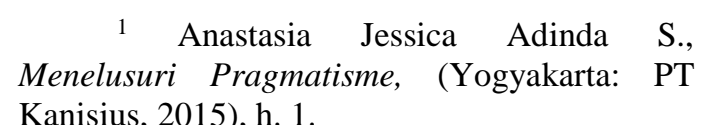

bagaimana suatu benda akan bertingkah jika ia mempunyai suatu sifat atau termasuk dalam satu jenis. Misalnya jika benda itu keras maka ia akan menggores benda lain, jika ia bersifat seperti bensin maka ia akan menguap dan lain-lain. Perhatian Peirce pada logika, terutama logika ilmiah atau lebih dikenal dengan metodologi begitu besar. $^{2}$ Dan inilah yang membuat pemikirannya sangat berpengaruh di dunia filsafat terutama di Amerika. Pemikiran Peirce juga mempengaruhi pemikiran Eropa melalui sahabatnya James dan Muridnya Dewey. ${ }^{3}$ Peirce telah memberikan sembangan pemikirannya yang terbesar di bidang logika. Mula-mula, ia menjelaskan jenis-jenis kebenaran.

\section{B. Biografi Charles Sanders Peirce}

Charles Sanders Peirce lahir di Cambridge, Massachussetts, 10 September 1839 dan meninggal di Milford, Pennsylvania, 19 April 1914. Ia merupakan anak kedua dari Menjamin Peirce dan Sarah Peirce. Chrales S. Peirce jenius, baik dalam

\footnotetext{
${ }^{2}$ Rodliyah Khuza'i, Dialog Epistemologi Mohammad Iqbal dan Charles S. Peirce, (Bandung: PT Refika Aditama, 2007), h. 35.

3 Bernard Delfgaauw, Filsafat Abad 20, terj. Soejono Soemargono, (Yogyakarta: PT Tiara Wacana Yogya, 1987), h. 66.
} 


\section{AL-MARSHAD: JURNAL ASTRONOMI ISLAM DAN ILMU-ILMU BERKAITAN \\ ISSN 2442-5729 (print) || ISSN 2598-2559 (online) \\ http://jurnal.umsu.ac.id/index.php/almarshad \\ DOI: 10.30596/jam.v5i1.2743 || Vol. 5, No. 1 Juni 2019}

filsafat maupun ilmu pengetahuan. Keahliannya di bidang ilmu pengetahuan tidak hanya terbatas pada diskursus geologi, kimia, dan fisika, tetapi juga termasuk apresiasi prosedur yang digunakan oleh para pendahu yang sukses dalam meningkatkan pengetahuan. Ia mengklaim telah berhubungan dengan pemikir-pemikir terbesar pada masanya dalam ilmu fisika dan telah memberikan kontribusi bagi matematika, optics, gravimetry, dan lain-lain. Sebelum masuk ke Harvard, pada usia 16 tahun, Peirce sudah melakukan training di laboratorium kimia selama sepuluh tahun, dan telah membaca logika Whitely. Pendidikannya di Harvard dikonsentrasikan pada filsafat dan ilmuilmu fisika. Di hari-hari studinya ia banyak sekali membaca literatur diluar tugas akademiknya. Peirce seorang pengkaji berat logika. Ia juga mengkaji masalah-masalah besar dari pemikiran yang muncul pada Abad Pertengahan, dengan tanpa melalaikan karya-karya (filsafat) Yunani, Inggris, Jerman, Prancis, dan lain-lain. Ia juga telah melahirkan sistem logika induktif. ${ }^{4}$ Dia Mohammad, h. 71 menulis dari tahun 1857 sampai menjelang wafat, kira-kira selama 57 tahun. Publikasinya mencapai 12.000 halaman dan manuskrip yang tidak dipublikasikan mencapai 80.000 halaman catatan tangan. Topik yang dibahas dalam karya- karya Peirce sangat luas, dari matematika dan ilmu fisika, ekonomi dan ilmu sosial, serta masalah lainnya. ${ }^{5}$

Ia tetap tinggal di perpustakaan untuk mengkaji masalah yang belum ia ketahui Ia telah menghabiskan waktunya dua jam sehari selama lebih tiga tahun untuk menekuni: "critique of Pure Reason" karya Immanuel Kant sehingga menguasai betul karya tersebut, dan dapat memberikn kritik pada setiap bagian. Ia setuju dengan Immanuel Kant dalam membuat pengetahuan relatif menuju pembentukan pemikiran manusia dan batas wilayah pengalaman yang mungkin. Seperti Kantian dan Peirce berusaha memisahakan secara total pengetahuan dan agama dengan membatasi keduanya menjadi wilayah-

5 Mustaqim, "Pragmatisme dalam Filsafat Kontemporer: Analisa atas Pemikiran Charles S. Peirce," Al-Mabsut: Jurnal Studi Islam dan Sosial 3 (2012), diakses 15 April 2018, doi: ejournal.iaingawi.ac.id 


\section{AL-MARSHAD: JURNAL ASTRONOMI ISLAM DAN ILMU-ILMU BERKAITAN \\ ISSN 2442-5729 (print) || ISSN 2598-2559 (online) \\ http://jurnal.umsu.ac.id/index.php/almarshad \\ DOI: 10.30596/jam.v5i1.2743 || Vol. 5, No. 1 Juni 2019}

wilayah yang berbeda, dengan menggunakan istilah Kant, bahwa wilayah yang memungkinkan bagi pengkaji ilmu dinamakan fenomenal, sedangkan wilayah yang tidak dapat dijangkau dengan ilmu pengetahuan dinamakan numenal. Ilmu pengetahuan dipandang tidak memberi kemajuan, tidak memberi hasil yang bermanfaat dan tidak memberikan hal-hal baru yang berafedah bagi hidup.

Setelah meneyelesaikan studi di Harvard University pada 1859, Pairce masuk ke Laurence hingga memperoleh gelar M. A pada 1862. Pada 1868, Ia menerima gelar Sc.B. dalam bidang kimia di Harvard dengan predikat Summa cum Laude. Peringkat ini merupakan predikat pertama kali diraih oleh mahasiswa di bidang kimia. Setelah itu, ia bekerja di United States Coast dan Geodetic Survey hingga 1891. Ia juga belajar klasifikasi biologi dibawah Louis Agassiz, lawan kuat Evolusi Darwin.

Peirce menikah pada 1862 dengan Marriet Melunisia Inadequasies yang akrab dengan panggilan Zina, feminis pertama di Amerika. Ia menumpahkan semangat pembaruannya dengan mengajak Peirce ke dalam persekutuan gereja Episcopal. Charles S. Peirce menjadi anggota gereja Episcopal dan mengakui adanya Trinitas. Usahanya yang awal adalah menegembangkan sistem tiga kategori karya Kant agar sesuai dengan Trinitas. Seperti dikatakan Ayer, bahwa pemikiran kategori ini hampir memasuki semua wilayah pemikirannya. Ketiga-tiganya disebut juga sebagai Three Fundamental Categories yang sewaktuwaktu merupakan model-model wujud dan kadang-kadang sebagai ide-ide. Disini tampak jelas bagaimana Pairce berusaha untuk memadukan antara agama, filsafat dan pengetahuan karena ajaran agama telah mengkristal dalam dirinya. Zina berusaha membantu Peirce dalam menghadapi kesulitan-kesulitan.

Dengan bantuan dan dorongan istrinya Peirce dapat meraih jabatan yang tinggi dalam kariernya. Sejak awal Peirce tertarik dengan logika ilmiah hingga akhir hayatnya. Serangkaian kuliah logika ilmiah Ia berikan di Harvard pada 1864-1865 di Boston.

Suatu peristiwa yang lebih penting selama masa 1870-an, secara rutin Peirce bertemu dengan sejumlah sarjana di Cambridge. Kemudian, kelompok ini dikenal dengan 


\section{AL-MARSHAD: JURNAL ASTRONOMI ISLAM DAN ILMU-ILMU BERKAITAN \\ ISSN 2442-5729 (print) || ISSN 2598-2559 (online) \\ http://jurnal.umsu.ac.id/index.php/almarshad \\ DOI: 10.30596/jam.v5i1.2743 || Vol. 5, No. 1 Juni 2019}

"Metaphisical Club". Untuk pertama kalinya, Peirce menyampaikan gagasannya tentang pragmatisme. Sejak itu, ia dikenal sebagai figur utama gerakan pragmatisme. Pada 1879-1884, ia mengajar di Hopkins University.

Untuk beberapa waktu (18751876), Peirce berangkat ke Atlantic demi meningkatkan ilmu di Eropa . Sekembalinya dari Eropa, ia menceraikan Zina dan kemudian menikah dengan Madame Juliette Pourtalai. Ia meneruskan kembali karya-karyanya pada 1878-1879 dengan title "The Fixation of Belief"dan "How to Make Our Ideas Clear”.

William James merupakan teman dekat Peirce, hingga salah satu karyanya yang berjudul "The Will to Belive" sengaja ditulis untuk dipersembahkan kepada Peirce. Setelah terakhir Peirce mengajar di Harvard Corporation, akhirnya Peirce memutuskan untuk pensiun dan menghabiskan masa hidupnya di pengasingan Milford, Pinennsylvania beserta Istrinya, Juliette. Antara Peirce dan William James ada keterbukaan dan keterus terangan dalam masalah kepercayaan, metode pragmatis dan masalah-masalah filsafat lainnya. Hal ini terlihat jelas dalam beberapa suratnya. Baik Henry, maupun William James menyadari kemampuankemampuan Peirce yang luar biasa, perhatian dan seluruh karyanya. Dalam pengasingannya di Pinennsylvania ia memanfaatkan waktunya dengan belajar, berpikir, dan menulis karya besar yang dia jadikan sebagai panutan. Bahkan sebagimana disebutkan oleh Morris R. Kohen, jika norma keberhasilan filsafat adalah hasil dari ide-ide penting yang radikal, dan bermanfaat, maka Pairce adalah figur terbesar dalam filsafat Amerika.

Setelah Peirce meninggal akibat kanker, Universitas Harvard membeli manuskripnya dari janda Peirce. Koleksi yang awal diedit oleh Morris R. Kohen dengan judul "Chance Love, and Logic” yang dipublikasikan pada 1923. Akan tetatapi, karya utamanya yang dipublikasikan oleh Harvard University diedit oleh Charles Harsthone dan Paul Weis dalam 60 volume, "The Collected Papers of Charles Sander Peirce" pada 1931-1935. Dua volume berikutnya diedit oleh Arthur W. Burk pada 1958. Volume ke delapan berisi bibliografi karya-karya Peirce, instrumen ilmiah yang bernilai besar disiapkan oleh Burk. 


\section{AL-MARSHAD: JURNAL ASTRONOMI ISLAM DAN ILMU-ILMU BERKAITAN \\ ISSN 2442-5729 (print) || ISSN 2598-2559 (online) \\ http://jurnal.umsu.ac.id/index.php/almarshad \\ DOI: 10.30596/jam.v5i1.2743 || Vol. 5, No. 1 Juni 2019}

Karya Peirce tidak berisi pengujian-pengujian masalah secara rinci, tetapi lebih merupakan sistematika seorang filsuf terutama perhatiannya terhadap masalah-masalah ilmu, kebenaran, dan pengetahuan yang landasnya telah diletakkan oleh Descartes dan Immanuel Kant. ${ }^{6}$

\section{Pragmatisme Charles S. Peirce}

Secara etimologis, pragmatisme berasal dari kata pragma (bahasa Yunani) yang berarti fakta, benda, materi sesuatu yang dibuat, kegiatan/tindakan, pekerjaan menyangkut akibat. Pragmatisme dapat diartikan sebahgai aliran pemikiran yang menekankan berfungsinya gagasan dalam tindakan.

Istilah 'Pragmatisme' diambil oleh Charles Sanders Peirce dari filsafat Kant. Dalam filsafat Kant terdapat dua kata yang mirip namun berbeda arti, yaitu praktisch (bahasa Yunani : praktikos) dan pragmatisch (dari pragmaticos). Istilah praktisch merujuk pada pengertian tindakan dengan tujuan pada dirinya sendiri sehingga pengertian tindakan ini hanya ada pada

6 Rodliyah, Dialog Epistemologi Mohammad, h. 71-73. ranah akal budi, bukan dalam pengalaman langsung. Sedangkan pragmatisch menekankan suatu gerakan dari kehendak manusia untuk melaksanakan tujuan definitif sebagai tahap penting untuk mengklarifikasi pemikiran. Sebutan 'keyakinan pragmatis' dalam karya Immanuel Kant berarti tingkat keyakinan hipotesis yang memiliki kemungkinan real untuk mencapai kemungkinan tertentu. Keyakinan pragmatis merupakan keyakinan-keyakinan yang berguna tetapi sifatnya masih kemungkinan. Keyakinan pragmatis bekerja seperti resep seorang dokter yang diyakini dapat menyembukan pasien. Gagasan dalam pragmatisme dinyatkan benar sejauh dapat merubah kenyataan atau tindakan. $^{7}$

Pada kira-kira tahun 1890 dimulailah suatu zaman yang baru, yang dalam banyak hal berbeda dengan zaman yang mendahuluinya, tetapi yang masih ada juga kesinambungannya. Abad ke-20 masih juga dijiwai oleh pandangan bahwa cara yang paling baik untuk menemukan kebenaran di bidang filsafat adalah cara yang dengan sadar

${ }^{7}$ Anastasia, Menelusuri Pragmatisme, h. 2. 


\section{AL-MARSHAD: JURNAL ASTRONOMI ISLAM DAN ILMU-ILMU BERKAITAN \\ ISSN 2442-5729 (print) || ISSN 2598-2559 (online) \\ http://jurnal.umsu.ac.id/index.php/almarshad \\ DOI: 10.30596/jam.v5i1.2743 || Vol. 5, No. 1 Juni 2019}

meninggalkan apa yang telah dapat disumbangkan oleh para pemikir yang terdahulu di bidang itu. Dengan demikian sifat individualistis yang telah tampak pada abad ke-19 menjadi berlarut-larut sehingga sering sukar sekali untuk mengerti pangkal pikiran para ahli pikir itu.

Pada umumnya pada bagian pertama abad ke-20 terdapat bermacammacam aliran yang berdiri sendirisendiri dan yang terdapat di bermacammacam negara. Masing-masing menyebarkan pengaruh yang mendalam dalam masyarakat di sekitarnya. Pada zaman parohan pertama abad ke-20 ini umpamanya terdapat aliran pragmatisme di Inggris dan Amerika, filsafat hidup di Prancis dan Jerman, fenomenologi dan masih ada lainya lagi. ${ }^{8}$

Pragmatisme memandang bahwa kriteria kebenaran ajaran adalah, faedah atau manfaat. Suatu teori atau hipotesis dianggap oleh pragmatisme benar apabila membawa suatu hasil. Dengan kata lain, suatu teori itu benar kalau berfungsi (if it works). Dengan demikian pragmatisme dapat

8 Harun Hadiwijono, Sari Sejarah Filsafat Barat 2, (yogyakarta: Kanisius, 1980), h. 130 . dikategorikan ke dalam pembahasan mengenai teori kebenaran (theory of truth), sebagaimana yang nampak menonjol dalam pandangan William James (1842-1910), terutama dalam bukunya "The Meaning of The Truth" (1909).

Menurut filsafat tersebut, Istilah pragmatisme ini kemudian di angkat pada tahun 1865 oleh Charles S. Peirce (1839-1914) sebagai doktrin pragmatisme. Doktrin itu selanjutnya di umumkan pada tahun 1978, paham tersebut menetapkan aspek-aspek praktis sebagai parameter benar salahnya suatu pemikiran atau konsep. Doktrin ini diangkat dalam sebuah makalah yang dimunculkan pada tahun 1878 dengan tema "How to Make Our Ideas Clear" yang kemudian dikembangkan oleh beberapa ahli filsafat Amerika diantaranya John Dewey (1859 - 1952). Chambers everyday dictionary merumuskan pragmatisme sebagai a philosophy or philosophycal method thats makes practical consequences the test of truth, yaitu suatu filsafat atau metode filsafat yang menetapkan hasil-hasil praktis sebagai standar kebenaran. 


\section{AL-MARSHAD: JURNAL ASTRONOMI ISLAM DAN ILMU-ILMU BERKAITAN \\ ISSN 2442-5729 (print) || ISSN 2598-2559 (online) \\ http://jurnal.umsu.ac.id/index.php/almarshad \\ DOI: 10.30596/jam.v5i1.2743 || Vol. 5, No. 1 Juni 2019}

Membicarakan pragmatisme sebagai sebuah paham dalam filsafat, memang tidak dapat dilepaskan dari nama-nama seperti Charles S. Peirce, William James, dan John Dewey di atas. Meskipun ketiga tokoh tersebut dimasukkan dalam kelompok pragmatisme, namun di antara ketiganya memiliki fokus pembahasan yang berbeda. Charles S. Peirce lebih dekat di sebut filsuf ilmu, sedangkan William James disebut filsuf agama, dan John Dewey dikelompokkan pada filsuf sosial. ${ }^{9}$ Namun William Jameslah orangnya yang memperkenalkan gagasan-gagasan pragmatisme itu kepada dunia.Pragmatisme adalah suatu aliran yang mengajarkan bahwa yang benar adalah apa yang membuktikan dirinya sebagai benar dengan perantaraan akibat-akibatnya yang bermanfaat secara praktis. ${ }^{10}$

\section{Kebenaran menurut Charles Sanders Peirce}

Peirce membagi kebenaran menjadi dua, pertama; Kebenaran Transendental (Trancendental Truth), yaitu kebenaran yang menetap pada benda itu

\footnotetext{
Filsafat".

9 Mustaqim, "Pragmatisme dalam

${ }^{10}$ Harun, Sari Sejarah Filsafat, h. 130.
}

sendiri.kedua; kebenaran kompleks (Complex Truth), yaitu kebenaran dalam pernyataan. Kebenaran kompleks dibagi menjadi kebenaran etis atau psikologis yaitu keselarasan pernyataan dengan apa yang diimani pembicara, dan kebenaran logis atau literal, yaitu keselarasan pernyataan dengan realitas yang didefinisikan. Semua kebenaran pernyataan ini harus diuji dengan konsekuensi praktis melalui pengalaman.

Langkah awal yang harus dilakukan dalam memahami pandangan besar Peirce tentang kebenaran adalah memahami adanya tiga sifat dasar yang ada keyakinan; pertama adanya proporsi, kedua adanya penilaian, dan yang ketiga adanya kebiasaan dalam pikiran.

Untuk mencapai sebuah keyakinan akan suatu, minimal harus ada tiga sifat dasar di atas. Pada gilirannya, keyakinan akan menghasilkan kebiasaan dalam pikiran (habit of mind). Berbagai kepercayaan dapat dibedakan dengan membandingkan kebiasaan dalam pikiran yang dihasilkan. Dari situ, Peirce kemudian membedakan antara keraguan dan keyakinan. Orang yang 


\section{AL-MARSHAD: JURNAL ASTRONOMI ISLAM DAN ILMU-ILMU BERKAITAN \\ ISSN 2442-5729 (print) || ISSN 2598-2559 (online) \\ http://jurnal.umsu.ac.id/index.php/almarshad \\ DOI: 10.30596/jam.v5i1.2743 || Vol. 5, No. 1 Juni 2019}

yakin pasti berbeda dengan orang ragu minimal dari dua hal: feeling and behavior. Orang yang ragu selalu merasa tidak nyaman dan akan berupaya untuk menghilangkan keraguan itu untuk menemukan keyakinan yang benar.

Gagasan Peirce tentang keyakinan dan pencarian keyakinan yang benar, Ia mengemukakan dua tipologi, yakni; fixation of belief, usaha untuk meneguhkan keyakinan yang telah dimiliki,agar bisa survive, dan Clarification of idea yang mencakup metafisika, etika dan logika. Peirce mengembangkan dalam bidang logika yang digagasnya dalam teori baru The New Logic (cara berfikir baru) dan The Logic of Inquiry (logika penelitian). Bagi Peirce, logic tidak statis tapi bersifat dinamis, sehingga dengan perkembangan ilmu pengetahuan, apa yang nampak sebagai fenomena dibaca dan dicerna dengan pembacaan yang kritis dan produktif.

Selanjutnya Peirce mengajukan lima konstruksi pemikiran yaitu;

1. Belief, berupa tatanan sosial yang dipegangi dan moral,
2. Habit of mind, kebiasaan dalam pikiran yakni adat istiadat yang turun temurun dan mengkristal,

3. Doubt, keragu- raguan akan apa yang selama ini dianggap mapan karena adanya benturan antara turath (warisan keilmuan Islam) dengan al-hadathah (modernitas). Untuk memperoleh keyakinan, menurut Peirce seorang peneliti perlu menggunakan empat, yakni; tenasitas, otoritas, apriori, dan investigasi,

4. Inquiry (penelitian), yang dicari adalah meaning (nilai) bukan truth (kebenaran)dan

5. The logic of theory. Peirce menegaskan bahwa kebenaran teks adalah sebagian kebenaran yang tertutup dalam kebenaran absolut. Dari sini, Peirce menewarkan perlunya Commonity of Research sehingga masing-masing kebenaran relatif tersebut masih dapat diapresiasi dan dikritik.

Peirce mengakui bahwa dalam sejarah manusia, usaha-usaha untuk mencari keyakinan yang benar itu setidaknya dilakukan dengan berbagai cara, diantaranya: 


\section{AL-MARSHAD: JURNAL ASTRONOMI ISLAM DAN ILMU-ILMU BERKAITAN \\ ISSN 2442-5729 (print) || ISSN 2598-2559 (online) \\ http://jurnal.umsu.ac.id/index.php/almarshad \\ DOI: 10.30596/jam.v5i1.2743 || Vol. 5, No. 1 Juni 2019}

1. A priori, yang berasal dari bahasa latin: $a$ (dari) dan prior (yang mendahului). A priori digunakan, kontras dengan a posteriori, untuk mengacu pada kesimpulankesimpulan kepada apa yang sudah di tentukan, bukan dari pengalaman. Oleh karena itu, $a$ priori mengacu kepada apa yang dapat kita asalkan dari definisi dan apa yang tersirat dalam makna ide yang sudah diterima. A priori berarti tidak bergantung pada pengalaman indrawi. Barangkali ilustrasi yang tepat untuk a priori tersebut faedah kasus penemuan obat malaria yang terjadi secara kebetulan. Seorang indian yang sakit minum air dikolam dan akhirnya mendapatkan kesembuhan. Hal ini terjadi berulang kali pada beberapa orang. Akhirnya, diketahui bahwa di sekitar kolam tersebut tumbuh sejenis pohon yang kulitnya bisa digunakan sebagai obat malaria yang kemudian berjatuhan di kolam tersebut. Penemuan pohon yang kelak di kemudian hari dikenal sebagai pohon kina tersebut adalah terjadi secara kebetulan saja.
2. Trial and Error, artinya coba-coba. Metode ini bersifat untunguntungan. Salah satu contoh ialah model percobaan problem box Thorndike. Percobaan tersebut adalah seperti berikut: seekor kucing yang kelaparan dimasukkan ke dalam problem box, suatu ruangan yang hanya dapat di buka apabila kucing berhasil menarik ujung tali dengan membuka pintu. Karena rasa lapar dan melihat makanan di luar maka kucing berusaha keluar dari kotak tersebut dengan berbagai cara. Akhirnya dengan tidak sengaja si kucing berhasil menyentuh simpul tali yang membuat pintu jadi terbuka dan dia pun berhasil keluar. Percobaan tersebut berdasarkan pada hal yang belum pasti, yaitu kemampuan kucing tersebut untuk membuka pintu kotak masalah.

3. Melalui otoritas. Kebenaran bisa didapati melalui otoritas seseorang yang memegang kekuasaan, seperti seorang raja atau pejabat pemerintah yang setiap keputusan dan kebijaksanaan dianggap benar oleh bawahannya. Dalam filsafat jawa dikenal dengan istilah sabda 


\section{AL-MARSHAD: JURNAL ASTRONOMI ISLAM DAN ILMU-ILMU BERKAITAN \\ ISSN 2442-5729 (print) || ISSN 2598-2559 (online) \\ http://jurnal.umsu.ac.id/index.php/almarshad \\ DOI: 10.30596/jam.v5i1.2743 || Vol. 5, No. 1 Juni 2019}

pandita ratu, ucapan pendeta atau ratu selalu benar dan tidak boleh di bantah lagi.

4. Melalui metode ilmiah dan investigasi. Metode ilmiah merupakan prosedur yang mencakup berbagai tindakan pikiran, pola kerja, tata langkah, dan cara teknis untuk memperoleh pengetahuan baru atau memperkembangkan pengetahuan yang ada. Selanjutnya dalam sebuah makalah yang terbit pada 1878, yang berjudul How I Make Our Ideas Clear, Peirce menyatakan bahwa kebenaran suatu pernyataan di ukur dengan kriteria apakah pernyataan tersebut bersifat fungsional dalam kehidupan praktis. Suatu pernyataan adalah benar apabila pernyataan dari konsekuensi dari pernyataan itu dipercaya mempunyai kegunaan praktis dalam kehidupan manusia. Kepercayaan atau keyakinan yang membawa pada hasil yang terbaik adalah yang menjadi justifikasi dari segala tindakan. Keyakinan yang meningkatkan suatu kesuksesan adalah kebenaran. Pragmatisme sebagai suatu interpretasi baru terhadap teori kebenaran oleh Peirce memang digagas sebagai teori arti. Dalam kaitan dengan ini: menurut teori pragmatis tentang kebenaran, suatu proposisi dapat disebut benar sepanjang proposisi itu berlaku atau memuaskan, berlaku dan memuaskannya itu diuraikan dengan berbagai ragam oleh para pengamat teori tersebut. Sementara itu, James menominalisasikan pragmatisme sebagai teori cash value. James kemudian menyatakan: ide-ide yang benar menurut James, adalah ide-ide yang dapat kita serasikan, kita umumkan berlakunya, kita kuatkan, dan kita periksa. Sebaliknya ide yang salah adalah ide yang tidak demikian.

Untuk membedakan dengan dua pendahulunya tersebut, Dewey menamakan pragmatisme, sebagai instrumentalisme. Instrumentalisme sebenarnya sebutan lain dari filsafat pragmatisme, selain eksperimentalisme. Dewey merumuskan instrumentalisme pragmatis sebagai to conceive of both knowledge and practice as means of making good excellencies of all kind secure in experienced existence. 


\section{AL-MARSHAD: JURNAL ASTRONOMI ISLAM DAN ILMU-ILMU BERKAITAN \\ ISSN 2442-5729 (print) || ISSN 2598-2559 (online) \\ http://jurnal.umsu.ac.id/index.php/almarshad \\ DOI: 10.30596/jam.v5i1.2743 || Vol. 5, No. 1 Juni 2019}

Demikianlah, Dewey pragmatisme dengan instrumentalism, operationalism, functionalism, dan experimentalisme. Menurut aliran tersebut, ide gagasan, pikiran dan intelegent merupakan alat atau instrumen untuk mengatasi kesulitan atau persoalan yang dihadapi manusia.

Peirce memaksudkan pragmatisme untuk membuat pikiran bisa menjadi ilmiah, tetapi James memandangnya sebagai sebuah filsafat yang dapat memecahkan masalahmasalah metafisik dan agama. Lebih jauh, James menganggapnya sebaga $i$ theory of meaning dan theory of truth.

Pragmatisme yang diserukan oleh James ini yang juga disebut practicalisme sebenarnya merupakan perkembangan dan olahan lebih jauh dari pragmatisme Peirce. Hanya saja, Peirce lebih menakankan pragmatisme ke dalam bahasa, yaitu untuk menerangkan arti-arti kalimat sehingga diperoleh kejelasan konsep dan perbedaannya dengan konsep lain. Dia menggunakan pendekatan matematik dan logika simbol yang pada gilirannya mengangkat namanya sebagai bapak semiotika modern, berbeda dengan James yang menggunakan pendekatan psikologi. Dengan semangat logika positivistik inilah, menurut beberapa tulisan, kemudian muncul sikap skeptis Peirce terhadap kemungkinan pengetahuan metafisik. Semangat logika positivistik menganggap semua pernyataan yang tidak terkait dengan benda-benda fisik- misalnya pernyataan etika dan metafisika- sebagai meaningless, tak bermakna atau omong kosong. John Passmore, misalnya, mengatakan bahwa kaum positivis menolak metafisika transendental atas dasar bahwa pernyataan-pernyataan itu tidak bermakna sama sekali. Namun demikian, kajian metafisika ini tetap diyakini Peirce dapat didiskusikan dan diselesaikan melalui filsafat. Salah satu masukan yang disumbangkan oleh telah dan kajian pragmatisme, juga filsafat analitik adalah analisisnya yang tajam tentang corak pemikiran metafisik yang terkait dengan world view (pandangan dunia) adalah monistic and pluralistic.

E. Implikasi Pragmatisme Charles S. Peirce Pada Penentuan Awal waktu Salat dan Pelaksanaannya

Dari sejarah munculnya aliran filsafat Pragmatisme oleh Peirce di Amerika ini penulis mencoba mencari implikasinya terhadap penentuan awal 


\section{AL-MARSHAD: JURNAL ASTRONOMI ISLAM DAN ILMU-ILMU BERKAITAN \\ ISSN 2442-5729 (print) || ISSN 2598-2559 (online) \\ http://jurnal.umsu.ac.id/index.php/almarshad \\ DOI: 10.30596/jam.v5i1.2743 || Vol. 5, No. 1 Juni 2019}

waktu salat dan pelaksanaan salat itu sendiri. Dari pengertian pragmatisme dapat diartikan aliran filsafat yang menekankan pengamatan penyelidikan dengan eksperimen (tindak percobaan) seta kebenaran-kebenaran yang mempunyai akibat-akibat yang memuaskan, dan juga Peirce mempunyai gagasan bahwa sesuatu hipotesis atau dugaan sementara itu benar bila bisa diterapkan dan dilaksanakan menurut tujuan kita.

Dari pengertian tersebut penulis mencoba melihat penentuan awal waktu salat dari kaca mata pragmatisme yang mana awal waktu salat itu merupakan sebuah waktu ibadah dimana dalam penentuannya membutuhkan eksperimen tindak percobaan untuk mengetahui keakuratan awal waktu salat tersebut dan juga penulis menghubungkannya kepada pelaksanaan salat itu sendiri. Mengingat pelaksanaan salat ini adalah sangat erat kaitannya dengan waktu apakah salat itu dilaksanakan sesuai dengan waktu yang telah ditemukan dilapangan dan bagaimana dampak salat itu sendiri kepada kehidupan, sehingga dari kaca mata pragmatisme salat ini dapat disebut sebagai sesuatu hal yang benar dari akibat yang ditimbulkan oleh salat, seperti dalam surat al-'Ankabut ayat 45:

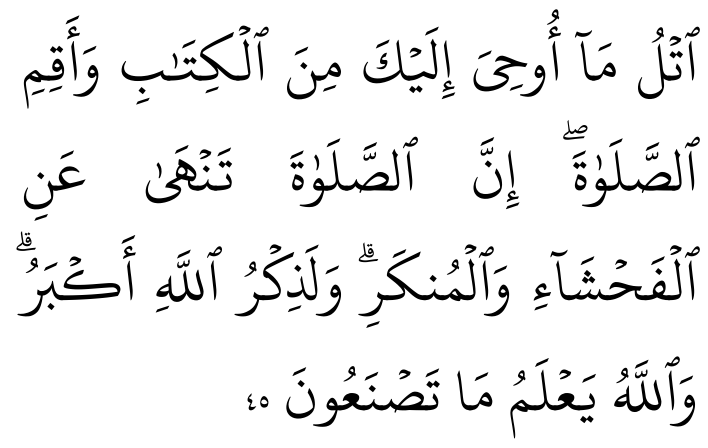

"Bacalah apa yang telah diwahyukan kepadamu, Yaitu Al kitab (Al Quran) dan dirikanlah shalat. Sesungguhnya shalat itu mencegah dari (perbuatanperbuatan) keji dan mungkar. dan Sesungguhnya mengingat Allah (shalat) adalah lebih besar (keutamaannya dari ibadat-ibadat yang lain). dan Allah mengetahui apa yang kamu kerjakan.”

\section{F. Pengertian Salat}

Secara lughawi atau arti kata salat (صلاة) mengandung beberapa arti; yang arti beragam itu dapat ditemukan contohnya dalam al-Qur'an. ${ }^{11}$ Ada yang berarti "do'a" sebagaimana dalam surat at-Taubah ayat 103:

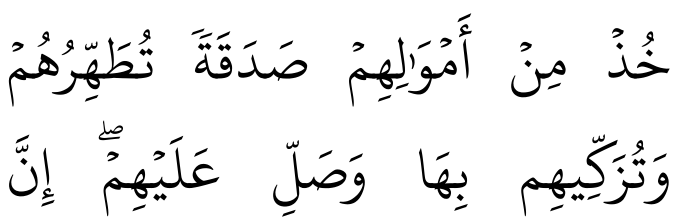

${ }^{11}$ Amir Syarifuddin, Garis-garis Besar Fiqh, (Jakarta: Kencana Prenadanedia Group, 2013), h. 20. 


\section{AL-MARSHAD: JURNAL ASTRONOMI ISLAM DAN ILMU-ILMU BERKAITAN \\ ISSN 2442-5729 (print) || ISSN 2598-2559 (online) \\ http://jurnal.umsu.ac.id/index.php/almarshad \\ DOI: 10.30596/jam.v5i1.2743 || Vol. 5, No. 1 Juni 2019}

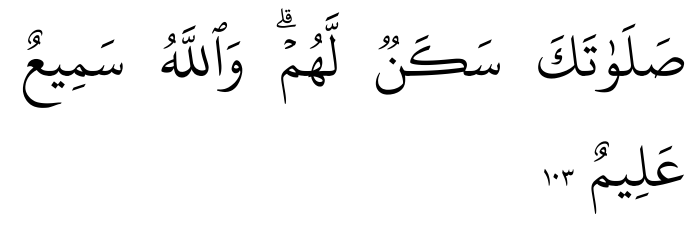

“:Berdo'alah untuk mereka, sesungguhnya do'a kamu itu (menjadi) ketentraman jiwa bagi mereka".

Kata salat juga dapat berarti memberi berkah, sebagaimana terdapat dalam surat al-Ahzab ayat 56:
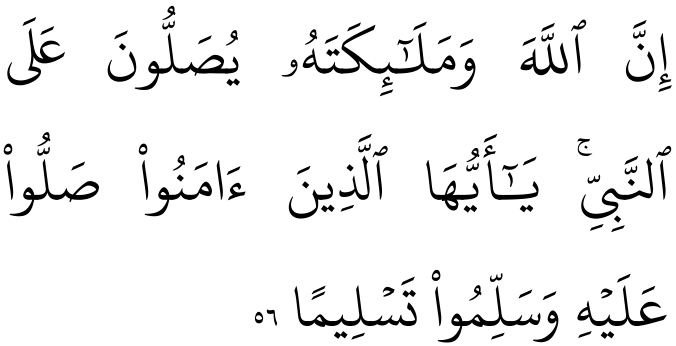

"Sesungguhnya Allah dan para malaikat-Nya memberi berkah kepada Nabi."

Secara terminologis ditemukan beberapa istilah diantaranya:

"Serangkaian perkataan dan perbuatan tertentu yang dimulai dengan takbir dan disudahi dengan salam". Dalam surat Thoha ayat 14, Allah AWT berfirman:

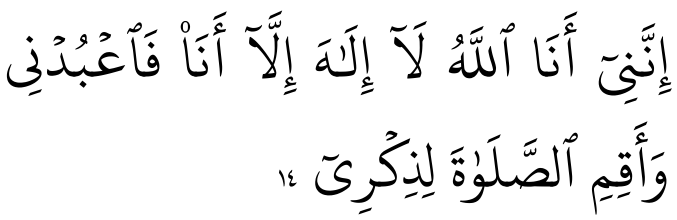

"Sesungguhnya aku ini adalah Allah, tiada tuhan selain Aku, maka sembahlah aku maka dirikanlah salat untuk mengingat-Ku.

\section{G. Hukum dan Dasar Salat}

Hukum salat adalah wajib 'aini dalam arti kewajiban yang ditujuikan kepada setiap orang yang telah dikenai beban hukum (mukallaf) dan tidak lepas kewajiban seseorang dalam salat kecuali bila telah dilakukannya sendiri sesuai dengan ketentuannya dan tidak dapat diwakilkan pelaksanaannya; karena yang dikehendaki Allah dalamperbuatan itu adalah berbuat itu sendiri tanda kepatuhannya kepada Allah yang menyuruh. Seperti firman Allah dalam surat al-Baqarah ayat 3 dan 5:

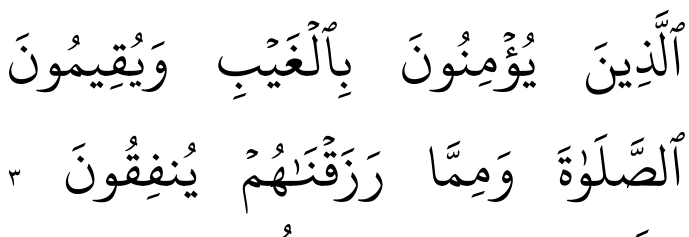

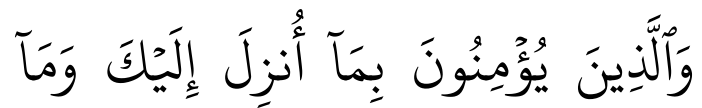

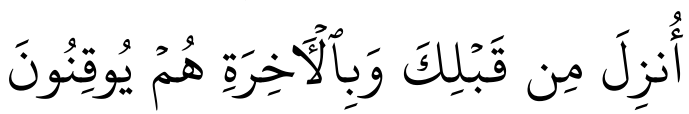

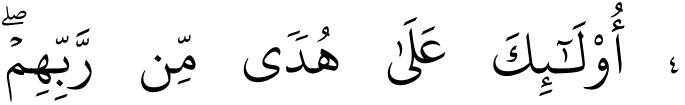

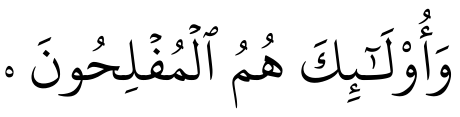
"(yaitu) mereka yang beriman kepada yang ghaib, yang mendirikan shalat, dan menafkahkan sebahagian rezki yang Kami anugerahkan kepada mereka. Mereka Itulah yang tetap mendapat petunjuk dari Tuhan mereka, dan merekalah orang-orang yang beruntung." 


\section{AL-MARSHAD: JURNAL ASTRONOMI ISLAM DAN ILMU-ILMU BERKAITAN \\ ISSN 2442-5729 (print) || ISSN 2598-2559 (online) \\ http://jurnal.umsu.ac.id/index.php/almarshad \\ DOI: 10.30596/jam.v5i1.2743 || Vol. 5, No. 1 Juni 2019}

\section{H. Waktu-waktu Salat}

Ibadah salat adalah ibadah yang telah ditentukan waktunya dan Allah telah menentukan waktu-waktu baginya. Firman Allah di dalam AlQur'an:

"Maka apabila kamu telah menyelesaikan shalat $(\mathrm{mu})$, ingatlah Allah di waktu berdiri, di waktu duduk dan di waktu berbaring. kemudian apabila kamu telah merasa aman, Maka dirikanlah shalat itu (sebagaimana biasa). Sesungguhnya shalat itu adalah fardhu yang ditentukan waktunya atas orangorang yang beriman".

Betapa pentingnya salat, sehingga di dalam rukun Islam, salat menempati urutan kedua setelah syahadat. ${ }^{12}$ Untuk mengetahui masuknya waktu salat tersebut Allah telah mengutus malaikat Jibril untuk memberi arahan kepada Rasulullah SAW tentang waktuwaktunya salat tersebut dengan acuan matahari dan fenomena cahaya langit yang notabene juga disebabkan oleh pancaran sinar matahari. Jadi sebenarnya petunjuk awal untuk mengetahui masuknya awal waktu salat adalah dengan melihat (rukyat) matahari.

12 Ahmad Musonnif, Ilmu Falak, (Yogyakarta: Penerbit teras, 2011), h. 57.
Untuk memudahkan kita dalam mengetahui awal masuknya waktu salat, kita bisa menggunakan perhitungan hisab, sehingga tidak harus melihat matahari setiap kali kita akan melaksanakan salat, terlebih dahulu kita harus mengetahui kriteria-kriteria masuknya waktu salat yang telah digariskan oleh Allah SWT.

Yang dimaksud waktu salat dalam pengertian hisab ialah awal masuknya waktu salat. Waktu salat habis ketika datang waktu salat berikutnya, ketika waktu salat subuh yang berakhit ketika munculnya matahari di ufuk timur. Waktu salat ditentukan berdasarkan posisi matahari diukur dari suatu tempat di mjuka bumi. Menghitung waktu salat pada hakekatnya ialah menghitung posisi matahari sesuai dengan kriteria yang ditentukan.

Sekiranya tidak menggunakan ilmu hisab, maka sudah barang tentu kita akan banyak mengalami kesulitan. Setiap saat kita akan melakukan salat Asar mislnya, setiap itu pula kita harus keluar rumah sambil membawa tongkat untuk diukur tinggi bayang-bayangnya. Setiap kita akan sembahyang Maghrib, maka setiap itu pula kita harus berusaha melihat apakah matahari sudah 


\section{AL-MARSHAD: JURNAL ASTRONOMI ISLAM DAN ILMU-ILMU BERKAITAN \\ ISSN 2442-5729 (print) || ISSN 2598-2559 (online) \\ http://jurnal.umsu.ac.id/index.php/almarshad \\ DOI: 10.30596/jam.v5i1.2743 || Vol. 5, No. 1 Juni 2019}

terbenam atau belum. Demikian pula seterusnya setiap kali kita akan sembahyang Isya, Shubuh dan Zhuhur, setiap itu pula kita harus melihat awan, fajar dan Matahari sebagai sebab datang atau habisnya waktu salat. ${ }^{13}$

Salat disyari'atkan dalam Islam pada bulan Rajab tahun ke-11 kennabian, saat Rasulullah Isra' dan Mi'rajkan ke Sidratil muntaha. Salat diwajibkan bagi umat Islam dalam sehari semalam sebanyak lima kali, yaitu Shubuh, Dhuhur, Ashar, Maghrib dan Isya', dalam surat ar-Ruum ayat 1718 dan surat al-Isra ayat 78 :

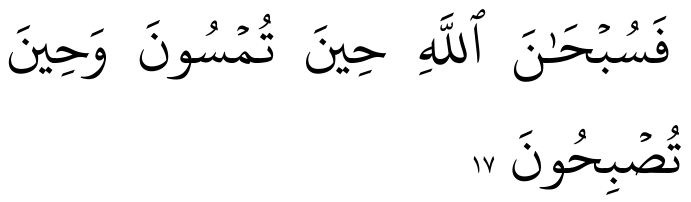

"Maka bertasbihlah kepada Allah di waktu kamu berada di petang hari dan waktu kamu berada di waktu subuh. Dan bagi-Nyalah segala puji di langit dan di bumi dan di waktu kamu berada pada petang hari dan di waktu kamu berada di waktu Zuhur.”

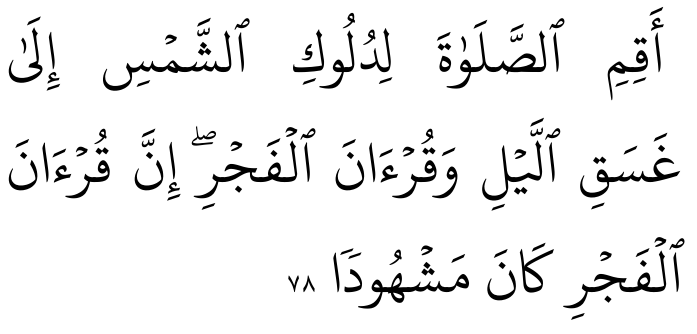

13 Departemen Agama RI, Almanak Hisab Rukyat, (Jakarta: 2010), 23.
"Dirikanlah salat dari sesudah matahari tergelincir sampai gelap malam dan (dirikanlah pula salat) subuh. Sesungguhnya salat subuh itu disaksikan (oleh malaikat)".

Dari beberapa ayat al-Qur'an yang menerangkan kriteria-kriteria awal waktu salat di atas kurang detail sehingga menimbulkan multi tafsir. Untuk memeperkuat ayat al-Qur'an di atas, berikut sebagian hadis yang secara rinci dan detail menerangkan waktuwaktu salat. Berikut salah satu hadis yang menjadi dasar penentuan waktu salat:

عن جا بر بن عبد الله قال جاء جبريل عليه السلام الى النبي صلى الله عليه وسلم حين زالت الثمس فقا ل قم با محمد فصل الظهرحين مالت الثمس ثم مكث حتى إذا كان فى ء ارجل مثله جا عه للعصر فقال قم يا محمد فصل العصر ثم مكث حتى إذا غا بت الثمس جا \&ه فقال فم فصل المغرب فقام فصلاها حين غا بت الثمس سواء ثم مكث حتى إذا ذحب الثفق جاءه فقال قم فصل العشاءفقام فصلاها ثم جا عه حين سطع الفجر في الصبح فقال كم با محمد فصلى فقام فصلى الصبح ثم جا \&ه من 


\section{AL-MARSHAD: JURNAL ASTRONOMI ISLAM DAN ILMU-ILMU BERKAITAN \\ ISSN 2442-5729 (print) || ISSN 2598-2559 (online) \\ http://jurnal.umsu.ac.id/index.php/almarshad \\ DOI: 10.30596/jam.v5i1.2743 || Vol. 5, No. 1 Juni 2019}

الغد حين كان في ء الر جل مثله فقال

قم يا محمد فصل فصلى الظهر ثم جاءه خبريل عليه السلام حين كا ن فيءالرجل مثليه فقال قم يا محمد فصل فصلى العصر ثم جاءه للمغرب حين غا

بت الثمس وقتا وا حدا لم يزل عنه فقا ل قم فصل فصلى المغرب ثم جا \&ه للعثاء حين ذاهب ثلث الليل الاول فقا ل قم فصل فصلى العشاء ثم جاءه للصبح حين اسفر جدان فقال قم فصل فصلى الصبح فقا ل ما بين هذين وقت كله.

"Dari Jabir bin Abdullah, Bahwasanya Jibril datang kepada Nabi SAW, lalu berkata kepadanya: Bangunlah dan bersalatlah, maka nabipun melakukan salat Dhuhur pada saat matahari telah tergelincir . kemudian datang pula Jibril kepada Nabi pada waktu Ashar, lalu berkata: bangunlah dan bersalatlah, maka Nabi melakukan salat Ashar pada saat bayangan matahari sama dengan panjang bendanya. Kemudian Jibril datang pula kepada Nabi waktu magrib, pada saat matahari telah terbenam. Kemudian jibril datang lagi pada waktu Isya' serta berkata: bangunlah dan bersalatlah, maka nabi melakukan salat Isya', pada saat mega merah telah hilang. Kemudian datang pula Jibril pada waktu subuh, lalu berkata: bangunlah dan bersalatlah, maka Nabi melakukan salat Subh pada saat fajar sadiq telah terbit. Pada keeskan harinya
Jibril datang lagi untuk waktu Dhuhur, Jibril berkata: bangunlah dan bersalatlah, maka Nabi melakukan salat Dhuhur pada saat bayangan matahari yang berdiri telah menjadi panjang. Kemudian Jibril datang lagi pada waktu Asar pada saat bayangan matahari dua kali sepanjang dirinya. Kemudian datag lagi Jibril pada waktu Maghrib pada saat waktu beliau datang kemarin juga. Kemudian datang lagi Jibril pada waktu Isya', diketika telah berlalu separuh malam, atau sepertiga malam, maka Nabi pun melakukan salat Isya', kemudian datang lagi jibril diwaktu telah terbit pajar sadiq, lalu berkata: bangunlah dan bersalatlah Subuh, sesudah itu Jibril berkata: waktu-waktu diantara kedua waktu ini: , itulah waktu salat." (HR. Imam Ahmad dan Nasai dan Tirmidzi).

Berdasarkan ayat-ayat dan hadits yang sebagian dikutip diatas dapat disimpulkan bahwa parameterparameter yang digunakan untuk menentukan waktu salat adalah dengan matahari. Akhirnya disimpulakan oleh para ulama empat madzhab bahwa awal waktu salat fardhu (lima waktu) sebagai berikut:

1. Dhuhur: dimulai ketika tergelincirnya matahari dari tengah langit (istiwa') ke arah barat ditandai dengan terbentuknya bayangan suatu benda sesaat setelah posisi matahari di tengah langit, atau bertambah panjangnya 


\section{AL-MARSHAD: JURNAL ASTRONOMI ISLAM DAN ILMU-ILMU BERKAITAN \\ ISSN 2442-5729 (print) || ISSN 2598-2559 (online) \\ http://jurnal.umsu.ac.id/index.php/almarshad \\ DOI: 10.30596/jam.v5i1.2743 || Vol. 5, No. 1 Juni 2019}

bayangan suatu benda, sesaat setelah posisi matahari di tengah langit dan waktu dhuhur berakhir ketika masuk waktu Asar. Yang dimaksud tengah langit bukanlah zenith akan tetapi di tengah-tengah langit diukur dari ufuk timur dan barat.

Padaa waktu zawal, yakni ketika matahari melewati garis zawal istiwa' (garis langit yang menghubungkan utara dan selatan) ada tiga kemungkinan arah bayangan benad yang berdiri tegak.

a. Pertama: arah bayangan berada di utara benda tersebut, yaitu ketika matahri melintasi zawal, posisinya berada di belahan langit selatan, azimuth $180^{\circ}$.

b. Kedua: arah bayangan berada di selatan benda tersebut, yaitu ketika matahari melintasi zawal, posisinya berada dibelahan langit utara, azimuth $0 \% 360^{\circ}$.

c. Ketiga: tidak ada bayangan sama sekali, yaitu ketika matahari melintasi zawal, posisinya tepat berada di ats zenith yak0ni posisi matahari berada pada sudut $90^{\circ}$ diukur dari ufuk. Diwilayah pulau Jawa fenomena ini hanya terjadi 2 kali di dalam setahun. Yang pertama antar tanggal 28 Februari sampai 4 Maret, sedangkan yang kedua natara 9 Oktober sampai 14 Oktober, di dalam bahas Jawa, fenomena ini disebut dengan Tumbuk.

Pada saat kondisi pertama dan kedua, bayangan suatu benda sudah ada pada saat zawal, sehingga masuknya , sehingga masuknya waktu dhuhur adalah bertambah panjang nya bayangan suatu benda tersebut sesaat setelah zawal.

Pada kondisi ketiga, pada saat zawal, suatu benda yang berdiri tegak tidak menimbulkan bayangan sedikitpun, sehingga masuknya waktu Dhuhur adalah ketika terbentuknya atau munculnya bayangan suatu benda sesaat setelah istiwa'/zawal. Waktu istiwa' atau waktu hakiki atau bisa juga disebut Waktu Syamsi, adalah waktu yang didasarkan pada peredaran (semu) Matahari yang sebenarnya. Ketika Matahari berkulminasi atas pasti jam 12 siang di tempat itu. Sehari semalam 


\section{AL-MARSHAD: JURNAL ASTRONOMI ISLAM DAN ILMU-ILMU BERKAITAN \\ ISSN 2442-5729 (print) || ISSN 2598-2559 (online) \\ http://jurnal.umsu.ac.id/index.php/almarshad \\ DOI: 10.30596/jam.v5i1.2743 || Vol. 5, No. 1 Juni 2019}

belum tentu 24 jam, adakala lebih dari 24 jam adakalanya kurang. Terjadinya perubahan waktu di permukaan Bumi ini sebenarnya merupakan akibat dari adanya perputaran Bumi pada porosnya, waktu istiwa' ini, dalam astronomi dikenal dengan solar time. ${ }^{14}$

Panjang bayangan saat datangnya waktu Dhuhur ini akan berpengaruh pula pada penentuan waktu Ashar.

2. Ashar: dimulai ketika panjang bayangan suatu benda, sama dengan panjang benda tersebut dan berakhir ketika masuk waktu Maghrib. Terkecuali pendapat Imam Abu Hanifah, bahwa masuknya waktu Ashar ialah ketika panjang bayangan suatu benda duakali dari panjang bendanya.

Dalam perhitungan waktu Ashar panjang bayangan pada waktu Dhuhur yang merupakan panjang bayangan minimum perlu diperhitungkan, karena suatu saat mungkin panjang bayangan saat Dhuhur itu lebih panjang dari tinggi benda itu sendiri, seperti di daerah Madinah yang lintangnya $24^{0} 28^{\prime}$,

14 Muhyiddin Khazin, Kamus Ilmu Falak, (Yogyakarta: Buana Pustaka, 2005), 90. pada bulan akhir bulan Desember deklinasi matahari- $23^{0}$ seingga pada waktu Dhuhur sudut matahari sudah mencapai $47^{0}$ lebih, dan tentunya pada saat Dhuhur, panjangn bayangan suatu benda sudah melebihi panjang benda itu sendiri, sehingga waktu Ashar adalah ketika panjang bayangan sebuah benda sama dengan panjang benda tersebut ditambah panjang bayangan waktu Dhuhur.

3. Maghrib: dimulai dari ketika terbenamnya semua bayangan matahari di ufuk barat yakni tenggelamnya piringan atas matahari di ufuk barat. Waktu Maghrib berakhir ketika masuk waktu Isya'.

4. Isaya': dimulai ketika hilangnya cahaya merah yang disebabkan tenggelamnya matahari dari cakrawala dan berkahir ketika masuk waktu Shubuh. Menurut asumsi ahli hisab kita, posisi matahari pada saat itu sekitar $-18^{0}$ dari ufuk barat, sebagian pendapat lainnya berkisar $-15^{0}$ smpai $-17,5^{0}$. sedangkan menurut Imam Abu Hanifah, ketika hilangnya cahaya 


\section{AL-MARSHAD: JURNAL ASTRONOMI ISLAM DAN ILMU-ILMU BERKAITAN \\ ISSN 2442-5729 (print) || ISSN 2598-2559 (online) \\ http://jurnal.umsu.ac.id/index.php/almarshad \\ DOI: 10.30596/jam.v5i1.2743 || Vol. 5, No. 1 Juni 2019}

putih yakni ketinggian matahari sekitar $-19^{0}$.

5. Shubuh: dimulai ketika munculnya Fajar Shodiq, yaitu cahaya keputihputihan yang menyebar di ufuk timur. Menurut asumsi ahli hisab kita posisi matahari pada saat itu sekitar $-20^{0}$ dari ufuq timur, sebagian pendapat lainnya berkisar $15^{0}$ sampai $19,5^{0}$, munculnya fajar shodiq ditandai dengan mulai pudarnya cahaya bintang. ${ }^{15}$

"Dan bertasbihlah kepada-Nya pada beberapa saat di malam hari dan di waktu terbenam bintang-bintang (di waktu fajar)."

Waktu shubuh berakhir ketika piringan atas matahari muncul di ufuq timur.

\section{Implikasi Salat di Awal Waktu}

Seorang muslim untuk beribadah kepada Allah SWT maka dia harus mentaati perintahnya salah satunya adalah salat, salah satu bentuk kesempurnaan salat adalah salat diawal waktu, seperti yang dijelaskan dalam hadis:

\footnotetext{
${ }^{15}$ Ahmad Musonnif, Ilmu Falak, h. 59-
}

$$
\text { الا من سمع الندا عفلم يأ تنه فلا صلا ة له }
$$

"Barang siapa mendengar panggilan adzan sedangkan dia tidak memenuhi panggilan itu, maka tidak ada salat yang sempurna baginya kecuali ada “udzur.”(HR. Ibnu Majah. Hadits Shahih).

Tentang keutamaan salat bayak terdapat dalam al-Qur'an, diantaranya dalam surat al-Ma'arij: 34-35:

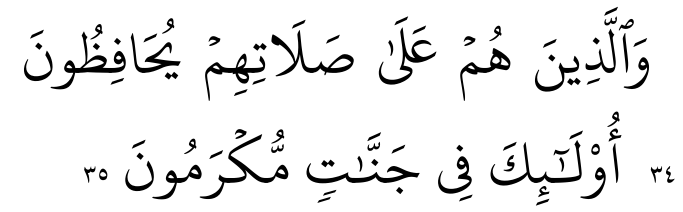

"Dan orang-orang yang memelihara shalatnya. Mereka itu (kekal) di syurga lagi dimuliakan".

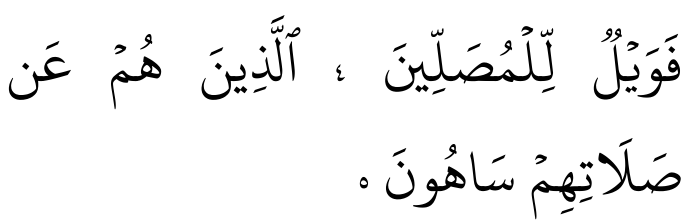

"Maka kecelakaanlah bagi orang-orang yang salat. Yaitu orang-orang yang lalai dalam salatnya." (Surat al-Ma'un: 4-5)

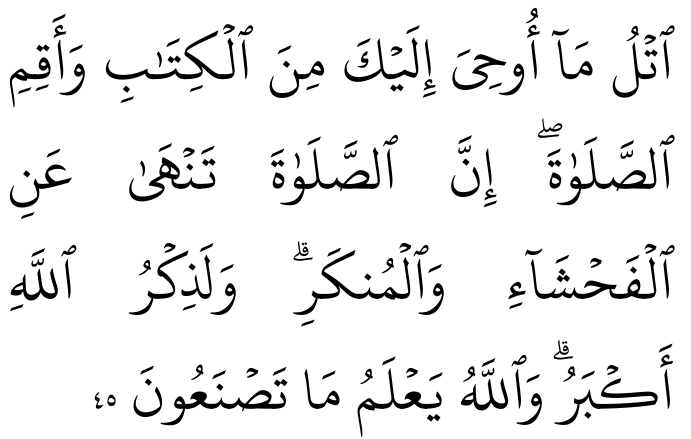

"Bacalah apa yang telah diwahyukan kepadamu, Yaitu Al kitab (Al Quran)

65. 


\section{AL-MARSHAD: JURNAL ASTRONOMI ISLAM DAN ILMU-ILMU BERKAITAN \\ ISSN 2442-5729 (print) || ISSN 2598-2559 (online) \\ http://jurnal.umsu.ac.id/index.php/almarshad \\ DOI: 10.30596/jam.v5i1.2743 || Vol. 5, No. 1 Juni 2019}

dan dirikanlah shalat. Sesungguhnya shalat itu mencegah dari (perbuatanperbuatan) keji dan mungkar. dan Sesungguhnya mengingat Allah (shalat) adalah lebih besar (keutamaannya dari ibadat-ibadat yang lain). dan Allah mengetahui apa yang kamu kerjakan.” (Surat al'Ankabut ayat 45)

Dapat dikatakan seorang muslim itu telah benar salatnya, apabila Ia telah mengaplikasikan tujuan daripada salatnya atau apabila salat itu memiliki akibat baik bagi dirinya yaitu terhindar dari perbuatan keji dan munkar seperti apa yang menjadi defenisi kebenaran dari pragmatisme yaitu kebenaran itu dibuktikan dengan kebenarannya sendiri. Jika salat tidak memberikan dampak yang baik bagi seseorang bisa dikatakan salatnya belum benar.

\section{J. Kesimpulan}

Charles S. Peirce (1839-1914) adalah tokoh yang mendengungkan aliran filsafat pragmatisme, walaupun dalam sejarahnya yang berperan penting dalam penyebaran filsafat pragmatisme ini adalah sahabatnya sendiri yaitu William James (1842-1910) dan juga John Dawey (1859-1952) juga tokoh filsafat Pragmatisme amerika setelah Peirce dan William James. Menurut Charles S. Peirce yang dimaksud dengan kebenaran yang hakiki adalah kebenaran menurut fakta bukan menurut opini, kebenaran menurut opini sangat tergantung kepada apa yang disepakati oleh orang yang membuat opini sedangkan kebenaran menurut fakta adalah nyata adanya.

Charles S. Peirce bukan hanya seorang filosof pendiri aliran pragmatisme tetapi Ia juga adalah seorang tokoh di bidang Matematika, geodesi, kimia dan fisikawan. Peirce dengan filsafat pragmatisme (filsafat bertindak) memandang bahwa sebuah hipotesa dianggap benar apabila dapat mendatangkan manfaat. Pragmatisme dikategorikan dalam teori kebenaran, Peirce membagi kebenaran menjadi dua, yaitu kebenaran transendental dan kebenaran kompleks. Kebenaran kompleks ini dibagi menjadi dua: kebenaran etis (psikologis) yaitu keselarasan pernyataan dengan yang diyakini si pembicara dan kebenaran logic (literal) yaitu keselarasan pernyataan dengan realitas yang didefenisikan. Peirce menggagas lima konstruksi pemikiran yaitu: belief, habit of mind, doubt, inquiry (research), and the new logic of theory. Sedangkan upaya mencari kebenaran dengan cara: 


\section{AL-MARSHAD: JURNAL ASTRONOMI ISLAM DAN ILMU-ILMU BERKAITAN \\ ISSN 2442-5729 (print) || ISSN 2598-2559 (online) \\ http://jurnal.umsu.ac.id/index.php/almarshad \\ DOI: 10.30596/jam.v5i1.2743 || Vol. 5, No. 1 Juni 2019}

a priori, trial and error, otoritas, serta melalui metode ilmiah dan investigasi.

Implikasinya terhadap penetuan waktu salat dan pelaksanaannya terlihat dari penetapan waktu salat yang dilakukan dengan cara pengamatan matahari menurut dalil al-Qur'an dan hadits sehingga sesuai dengan yang dimaksud sehingga waktu salat bisa akurat. Dan pelaksanaan salat dilihat dari sisi pragmatisnya, apakah salat itu memberikan manfaat atau tidak sehingga jelaslah tujuan salat itu selain dari perwujudan ibadah tetapi juga sebagai pencegah dari perbuatan yang keji dan mungkar. Seperti yang telah menjadi tujuan pemikiran pragmatisme yaitu tindakan atau hasil yang memberikan manfaat.

\section{Daftar Pustaka}

Delfgaauw, Bernard. Filsafat Abad 20, terj. Soejono Soemargono, Yogyakarta: PT Tiara Wacana Yogya, 1987.

Departemen Agama RI, Almanak Hisab Rukyat, Jakarta: 2010.

Hadiwijono, Harun. Sari Sejarah

Filsafat Barat 2, yogyakarta:

Kanisius, 1980.
Khazin, Muhyiddin. Kamus Ilmu Falak, Yogyakarta: Buana Pustaka, 2005. Khuza'i, Rodliyah. Dialog Epistemologi Mohammad Iqbal dan Charles S. Peirce, Bandung: PT Refika Aditama, 2007.

Musonnif, Ahmad. Ilmu Falak,

Yogyakarta: Penerbit teras, 2011.

Mustaqim, "Pragmatisme dalam Filsafat

Kontemporer: Analisa atas

Pemikiran Charles S. Peirce," Al-

Mabsut: Jurnal Studi Islam dan

Sosial 3 (2012), diakses 15 April

2018, doi: ejournal.iaingawi.ac.id Syarifuddin, Amir. Garis-garis Besar

Fiqh, Jakarta: Kencana

Prenadanedia Group, 2013.

S., Anastasia Jessica Adinda. Menelusuri Pragmatisme,

Yogyakarta: PT Kanisius, 2015. 